\title{
Predator/prey ratios: a measure of bark-beetle population status influenced by stand composition in different French stands after the 1999 storms
}

\author{
Nathalie WARZÉE*, Marius GILBERT, Jean-Claude GRÉGOIRE \\ Lutte biologique et Écologie spatiale, CP 160/12, Université Libre de Bruxelles, 50 av. FD Roosevelt, 1050 Bruxelles, Belgium
}

(Received 25 January 2005; accepted 12 October 2005)

\begin{abstract}
This study presents the results of a four-year trapping experiment in stands heavily infested by Ips typographus following the 1999 storms in north-eastern France. Ten bottle-traps were stapled on dead spruces or on broad-leaves in five spruce stands, among which two comprised pines, a species particularly favourable for the pupation of the predator, Thanasimus formicarius. The phenology of $T$. formicarius closely reflected that of its prey in all stands. We show that the proportion of pines within a $500 \mathrm{~m}$ radius is the main variable influencing predator/prey ratios, and that this variable alone outperforms other forest composition indices such as the Shannon diversity index estimated using all tree categories, or reduced to integrate only three categories (spruce, pine, others). These results are discussed with regard to the possible role of host trees and host-tree diversity in both insects' life-cycles and how the $T$. formicarius/Ips typographus ratios could be used to describe the status of Ips typographus infestations.
\end{abstract}

biodiversity index / biological control / Ips typographus / Scolytidae / Shannon index / Thanasimus formicarius / Cleridae

Résumé - Les ratios prédateur/proies : une mesure des populations de scolytes influencée par la composition du peuplement dans différents sites français après les tempêtes de 1999. Cette étude présente les résultats de quatre années de piégeage dans des peuplements fortement infestés par Ips typographus suite aux tempêtes de 1999 dans le nord-est de la France. Dix pièges-bouteilles ont été agrafés sur des épicéas morts ou des feuillus dans cinq pessières, dont deux comprenaient des pins, arbres particulièrement favorables à la nymphose du prédateur. La phénologie de T. formicarius a étroitement reflété celle de sa proie dans tous les sites. Nous montrons que la proportion de pins dans un rayon de $500 \mathrm{~m}$ est la principale variable influençant les ratios prédateur/proies, et que cette variable seule surpasse les autres indices du paysage, tels que l'indice de diversité de Shannon estimé avec toutes les catégories d'arbres, ou réduit seulement à trois catégories (pins, épicéas, autres). Ces résultats sont discutés en fonction du rôle éventuel des arbres hôtes et de leur diversité en ce qui concerne les cycles vitaux des deux insectes, ainsi que le moyen d'utiliser les ratios T. formicarius/Ips typographus pour décrire les infestations d'Ips typographus.

index de biodiversité / contrôle biologique / Ips typographus / Scolytidae / index de Shannon / Thanasimus formicarius / Cleridae

\section{INTRODUCTION}

The aim of this study was to determine if, and under which conditions, it would be possible to use predator/prey ratios to determine the local population status of a bark-beetle forest pest.

Ips typographus (L.) (Coleoptera: Scolytidae) is one of the most harmful bark beetles in Eurasia [12]. Epidemic population developments are only observed following storms and largescale wind-felled spruce damage providing abundant breeding material. Thanasimus formicarius (L.) (Coleoptera: Cleridae) exerts a significant impact on the population dynamics of $I$. typographus $[17,18,29,30]$ because of its high fecundity (106$162 \mathrm{eggs} /$ female $[5,30])$ and its high voracity at the adult stage
(0.86 to 2-3 adult I. typographus per day $[7,30])$ as well as at the larval stage (44-57 prey larvae during the whole larval life: $[5,13,17])$. It responds to the pheromone components of different bark-beetle species, including Ips typographus [2, 14, 27]. It is known to attack 27 species [9, 16, 27], among which 15 species on spruce, 13 on pine, 10 on fir, 4 on larch and 5 on various broadleaves $[3,21]$. Adults feed on bark-beetle adults and lay eggs on infested trees. Larvae move to the subcortical region of the trees, feed on bark-beetle immature stages and finally pupate in niches excavated in the outer bark.

In the USA, a similar predator/prey complex exists with the southern pine beetle (SPB) Dendroctonus frontalis Zimm. (Coleoptera: Scolytidae) and its predator Thanasimus dubius (F.) (Coleoptera: Cleridae): adult T. dubius are in high abundance

\footnotetext{
* Corresponding author: nathalie.warzee@ skynet.be
} 
Table I. Location and characteristics of the study sites.

\begin{tabular}{|c|c|c|c|c|c|c|c|c|}
\hline Site & $\begin{array}{c}\text { Location } \\
\text { (department) }\end{array}$ & $\begin{array}{l}\text { Elevation } \\
\quad(\mathrm{m})\end{array}$ & $\begin{array}{c}\text { Area } \\
\text { (ha) }\end{array}$ & $\begin{array}{l}\text { Age } \\
\text { (year) }\end{array}$ & $\begin{array}{c}\text { Species } \\
\text { composition }\end{array}$ & $\begin{array}{c}\text { Species } \\
\%\end{array}$ & $\begin{array}{c}\text { Trapping } \\
2001\end{array}$ & $\begin{array}{c}\text { Trapping } \\
2002,2003,2004\end{array}$ \\
\hline HA & Hanau (Moselle) & 260 & 25 & $110-130$ & $\begin{array}{l}\text { Spruce } \\
\text { Pine } \\
\text { Oak } \\
\text { Beech }\end{array}$ & $\begin{array}{c}5 \\
26 \\
49 \\
16\end{array}$ & yes & yes \\
\hline ST & Steinbach (Bas-Rhin) & 260 & $<33$ & 150 & $\begin{array}{l}\text { Pine } \\
\text { Spruce } \\
\text { Oak }\end{array}$ & $\begin{array}{l}80 \\
10 \\
10\end{array}$ & yes & yes \\
\hline DO & $\begin{array}{c}\text { Donon } \\
\text { "La Chatte Pendue" } \\
\text { (Bas-Rhin) }\end{array}$ & 900 & 54 & 120 & $\begin{array}{l}\text { Spruce } \\
\text { Fir } \\
\text { Beech }\end{array}$ & $\begin{array}{l}50 \\
40 \\
10\end{array}$ & no & yes \\
\hline GU & $\begin{array}{l}\text { Guebwiller } \\
\text { (Haut-Rhin) }\end{array}$ & 1100 & 14 & $140-170$ & $\begin{array}{l}\text { Spruce } \\
\text { Beech } \\
\text { Maple } \\
\text { Fir }\end{array}$ & $\begin{array}{c}34 \\
51 \\
7 \\
7\end{array}$ & yes & yes \\
\hline $2 \mathrm{~L}$ & Deux Lacs (Haut-Rhin) & 1100 & 20 & $110-130$ & Spruce & 100 & yes & yes \\
\hline
\end{tabular}

on the bark surface of attacked trees, can inflict more than $60 \%$ mortality to SPB adults and their densities exhibit yearly oscillations phase-shifted with respect to those of SPB $[24,28]$. In the USA, a predator/prey model based upon the T. dubius/D. frontalis ratio was even developed and tested in selected states in 1986-1987 to forecast SPB population trends [4], and was proven effective enough to be used as a decision-support utility by the US Forest Service [1].

However, this predator/prey relationship seems more complex in Europe than in North America. The stands where Ips typographus outbreaks occur differ from the often pure Pinus taeda or P. echinata stands in southern US by different degrees of tree mixtures, providing alternative prey but also variably suitable pupation sites to the predators, with pines offering more favourable pupation sites in their thick outer bark than spruces which have a thinner bark (Grégoire et al., submitted).

This study follows the heavy storms of December 1999 in France, which struck about 140 millions $\mathrm{m}^{3}$ of timber at the national scale (Inventaire Forestier National: http://www.ifn.fr/ pages/fr/tempetes/index.html) and triggered bark-beetle outbursts in all affected areas [10]. We tested the possibility of using comparative $T$. formicarius/Ips typographus catches as indicators of Ips typographus infestation trends but, whilst in USA only two variables are sufficient to predict Dendroctonus infestation dynamics (the mean numbers of SPB/trap/day and the relative abundance of SPB in relation to predators [1]), it was expected that, in the more complex French stands, a similar model would also need to account for tree species diversity. Populations of Ips typographus and T. formicarius were followed using pheromone/kairomone trapping during four years in five sites, in relation to landscape biodiversity and within different spatial scales (within the stand proper, within a $500 \mathrm{~m}$ radius, within a $1000 \mathrm{~m}$ radius). Tree species diversity was characterized in each site using one of the most popular diversity indices, the Shannon diversity index (SHDI) [25, 26] which emphasizes the richness component of diversity [19]. As this index is a global measure of landscape composition and does not make any distinction between tree species, we also tested if the proportion of pines alone may be sufficient to characterize each site and explain the difference among the predator/prey ratios.

\section{MATERIALS AND METHODS}

\subsection{Field experiment}

The trapping experiment was set-up in four sites in 2001 and five sites in 2002, 2003 and 2004 (Tab. I), during the following periods: 7 June to 17 September 2001, 16 May to 13 September 2002, 16 April to 8 October 2003 and 29 April to 15 September 2004.

During the four years, ten $30 \times 15 \mathrm{~cm}$ "bottle-traps" [11] were stapled on broad-leaves or dead coniferous trees in each site. Living spruces or pines were not used to support traps in order to prevent inducing new attacks. The traps were baited with a commercial lure for Ips typographus, Pheroprax ${ }^{\circledR}$ (Cyanamid Agro, Gembloux, Belgium), racemic ipsdienol and exo-brevicomin (respectively, $40 \mathrm{mg}$ in bubblecaps and $250 \mu \mathrm{L}$ in Eppendorf vials: Pherotech Inc., Vancouver, Canada). The collecting bottle of each trap was half-filled with car antifreeze (ethylene-glycol) as a preservant. The traps were distant from each other by $15-20 \mathrm{~m}$ along a winding course in the stand. They were inspected seven or eight times each year. These inspections were synchronised between sites but also between years to compare barkbeetle and predator abundances from year to year (GLM analysis in SPSS 11.5).

\subsection{Data analysis}

In each site, maps of the stands where the traps were set-up and of the neighbouring stands within a $1 \mathrm{~km}$ radius were provided by the French Forest Health Department and compared with DEFORPA data (stand information dating from 1989-1990; L.-M. Nageleisen, pers. comm.). The map of each stand was then imported in ArcView GIS 3.2 and tree composition was assigned for each stand. To update the stand composition and density data after the December 1999 storms, aerial photographs taken some days after the storms (infrared colours; 1:17 000) were analysed with a binocular lens (Leica MZ6, enlargement 6 to 40). Within each site, the proportion of each tree species was calculated around the group of 10 bottle-traps within a $500 \mathrm{~m}$ and a $1000 \mathrm{~m}$ radius, using ArcView GIS 3.2 (Spatial Analyst). Then, to 
Table II. Categories of tree proportions used for the calculation of the Shannon diversity index.

Categories (species or groups of species)

\begin{tabular}{|c|c|c|c|c|c|c|}
\hline Pinus L. spp. & $\mathrm{x}$ & $\mathrm{x}$ & $\mathrm{x}$ & $\mathrm{x}$ & $\mathrm{x}$ & $\mathrm{x}$ \\
\hline Picea A. Dietr. spp. & $\mathrm{x}$ & $\mathrm{x}$ & $\mathrm{x}$ & $\mathrm{x}$ & $\mathrm{x}$ & $\mathrm{x}$ \\
\hline Abies Mill. spp. & $\mathrm{x}$ & & & & & \\
\hline Larix Mill. spp. & $\mathrm{x}$ & & & & & \\
\hline Pseudotsuga menziesii Carr. & $\mathrm{x}$ & & & & & \\
\hline Fagus L. spp. & $\mathrm{x}$ & $\mathrm{x}$ & $\mathrm{x}$ & $\mathrm{x}$ & & \\
\hline Quercus L. spp. & $\mathrm{x}$ & $\mathrm{x}$ & $\mathrm{x}$ & $\mathrm{x}$ & & \\
\hline Fraxinus L. spp. & $\mathrm{x}$ & $\mathrm{x}$ & & & & \\
\hline Betula L. spp. & $\mathrm{x}$ & $\mathrm{x}$ & & & & \\
\hline Acer L. spp. & $\mathrm{x}$ & & & & & \\
\hline Alnus Gaertn. spp. & $\mathrm{x}$ & & & & & \\
\hline Sorbus L. spp. & $\mathrm{x}$ & & & & & \\
\hline Tilia L. spp. & $\mathrm{x}$ & & & & & \\
\hline Empty space & $\mathrm{x}$ & & & & & \\
\hline Coniferous trees & & $\mathrm{x}$ & $\mathrm{x}$ & & & \\
\hline Broad-leaved trees & & & & & $\mathrm{x}$ & \\
\hline Other species & $\mathrm{x}$ & $\mathrm{x}$ & $\mathrm{x}$ & $\mathrm{x}$ & $\mathrm{x}$ & $\mathrm{x}$ \\
\hline Number of categories & 15 & 8 & 6 & 5 & 4 & 3 \\
\hline
\end{tabular}

characterize tree species diversity in each site, the Shannon diversity index (SHDI) $[25,26]$ was calculated as follows:

$$
\text { SHDI }=-\sum_{i=1}^{N} p_{i} \ln \left(p_{i}\right)
$$

in which $N$ is the number of land cover types (tree species) and $p_{i}$ the proportional abundance of the $i$ th type (relative areas covered by each species). As the number of tree species increases, this index produces values ranging from 0 (when the landscape is composed by only one tree species) to infinity [15]. The calculation of this index was made at different scales (stand level and radii of $500 \mathrm{~m}$ and $1000 \mathrm{~m}$ around the traps) and for different numbers of tree categories (Tab. II), starting with all the tree species listed in the sites, down to the 3 main categories relevant for $T$. formicarius (pines, spruces and other species). The grouping of tree species into a same tree category was made according to the potential prey available for $T$. formicarius on those trees: for example, Pseudotsuga menziesii Carr., Sorbus L. spp. and Tilia L. spp., in which no prey of $T$. formicarius is known, were grouped into the category "other species".

Bivariate correlations and regression analyses were performed (SPSS 11.5) between both catches of T. formicarius, of I. typographus and predator/prey ratios, and both the Shannon diversity (SHDI) index and the proportion of pines (PROP_PIN) around the 10 bottle-traps of each site.

The comparison of predator/prey ratios between sites and years was carried out using a two-way analysis of variance of the angular transform of the predator/prey ratio, with the site, year, and their interaction entered as fixed factors.

\section{RESULTS}

\subsection{Trapping data}

The total catches of Ips typographus decreased from 2001 to 2004 (GLM analysis; $\left.F_{1 ; 180}=48.081, P<0.0005\right)$ and all sites were not similar in this respect (GLM analysis; site $\times$ year effect; $F_{4 ; 180}=6.042, P<0.0005$ ) (Fig. 1): the difference
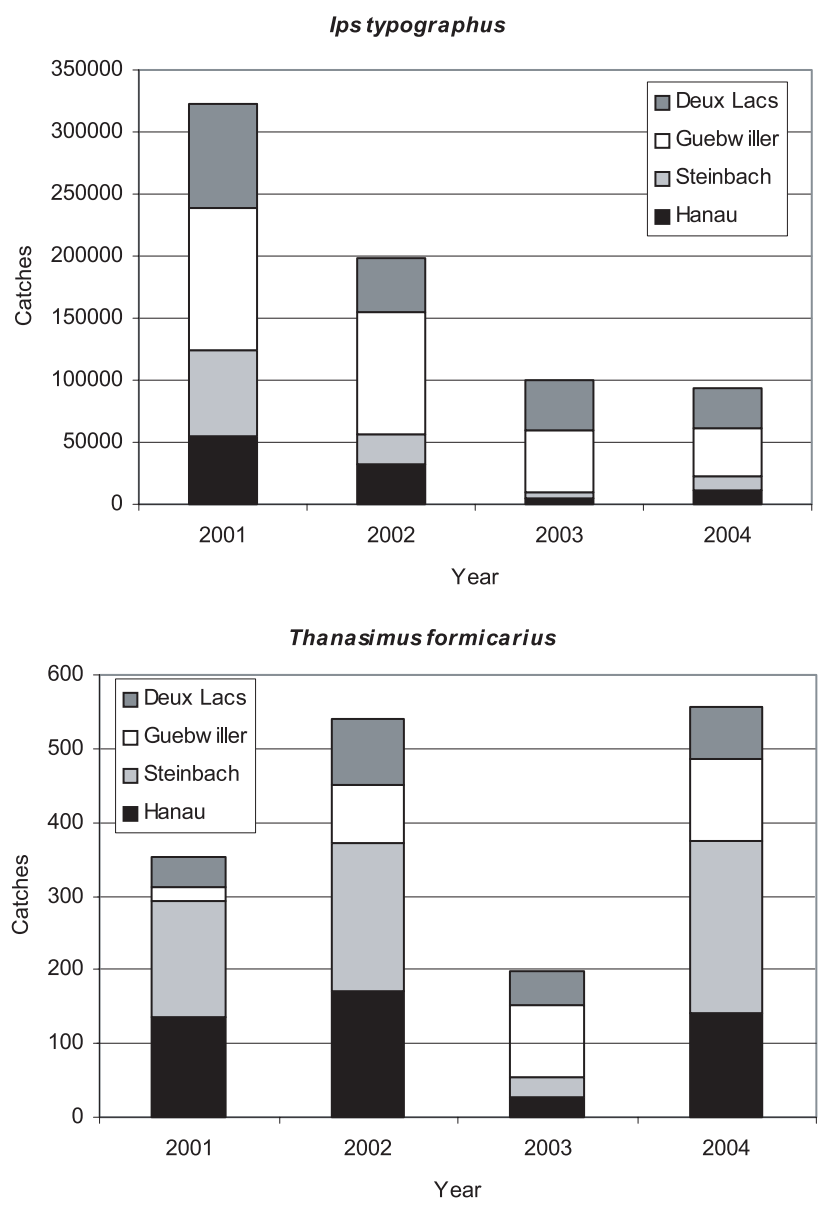

Figure 1. Changes in total catches of Ips typographus and Thanasimus formicarius from 2001 to 2004 in four of the study sites (from 10 June to 15 September). 
Table III. Trap catches during time intervals $(16 / 04-16 / 05,16 / 05-10 / 06, \ldots)$ common for the four-year trapping experiment.

\begin{tabular}{|c|c|c|c|c|c|c|c|c|c|c|c|c|c|}
\hline & & \multicolumn{6}{|c|}{ I. typographus } & \multicolumn{6}{|c|}{ T. formicarius } \\
\hline & & $16 / 04$ & $16 / 05$ & $10 / 06$ & $13 / 09$ & $08 / 10$ & Total & $16 / 04$ & $16 / 05$ & $10 / 06$ & $13 / 09$ & $08 / 10$ & Total \\
\hline \multirow{4}{*}{ HA } & 2001 & - & - & 54572 & - & & 54572 & - & - & 135 & - & & 135 \\
\hline & 2002 & - & 8795 & 32583 & - & & 41378 & - & 100 & 171 & - & & 271 \\
\hline & 2003 & 13505 & 10239 & 5087 & 108 & & 28939 & 34 & 42 & 26 & 0 & & 102 \\
\hline & 2004 & 1753 & 11954 & 11281 & - & & 24988 & 17 & 59 & 141 & - & & 217 \\
\hline \multirow{4}{*}{ ST } & 2001 & - & - & 70177 & - & & 70177 & - & - & 159 & - & & 159 \\
\hline & 2002 & - & 13137 & 23086 & - & & 36223 & - & 125 & 201 & - & & 326 \\
\hline & 2003 & 18215 & 11851 & 4848 & 8 & & 34922 & 42 & 53 & 27 & 0 & & 122 \\
\hline & 2004 & 3983 & 4847 & 10718 & - & & 19548 & 23 & 86 & 233 & - & & 342 \\
\hline \multirow{4}{*}{ DO } & 2001 & - & - & - & - & & - & - & - & - & - & & - \\
\hline & 2002 & - & 7384 & 96118 & - & & 103502 & - & 12 & 119 & - & & 131 \\
\hline & 2003 & 43994 & 8771 & 41248 & 1500 & & 95513 & 5 & 5 & 47 & 3 & & 60 \\
\hline & 2004 & 9665 & 4141 & 112086 & - & & 125892 & 0 & 2 & 105 & - & & 107 \\
\hline \multirow{4}{*}{ GU } & 2001 & - & - & 113776 & - & & 113776 & - & - & 17 & - & & 17 \\
\hline & 2002 & - & 89370 & 98618 & - & & 187988 & - & 11 & 79 & - & & 90 \\
\hline & 2003 & 27129 & 20477 & 49018 & 468 & & 97092 & 17 & 21 & 99 & 1 & & 138 \\
\hline & 2004 & 9 & 10019 & 38723 & - & & 48751 & 0 & 49 & 113 & - & & 162 \\
\hline \multirow{4}{*}{$2 \mathrm{~L}$} & 2001 & - & - & 83481 & - & & 83481 & - & - & 41 & - & & 41 \\
\hline & 2002 & - & 11905 & 44262 & - & & 56167 & - & 15 & 88 & - & & 103 \\
\hline & 2003 & 6373 & 12777 & 41026 & 367 & & 60543 & 12 & 15 & 46 & 1 & & 74 \\
\hline & 2004 & 441 & 22279 & 32749 & - & & 55469 & 1 & 12 & 70 & - & & 83 \\
\hline
\end{tabular}

among years was the strongest in Hanau $(P=0.001)$ and Steinbach $(P<0.0005)$. The $T$. formicarius catches increased from 2001 to 2002, then decreased in 2003 and increased again in 2004 (Fig. 1). Among the total T. formicarius catches, a year effect was observed (GLM analysis; $F_{1 ; 180}=9.605, P=0.002$ ), as well as a site effect (GLM analysis; $F_{4 ; 180}=11.515$, $P<0.0005)$. The catches in the two sites comprising pines were significantly higher than in the three other sites (without pines) $(P<0.05)$. The interaction between years and sites was also significant (GLM analysis; $F_{4 ; 180}=5.436, P<0.0005$ ), corresponding to a year effect different among each site. The detailed catches are described in Table III.

The predator/prey ratios (Tab. IV) were clearly higher in HA and ST (the two sites with pines) than in GU and 2L, and all ratios tend to increase with years (two-way ANOVA using arcsine-transformed ratios of individual traps; there was no significant interaction of site and years).
Table IV. Thanasimus formicarius/Ips typographus ratios (10 June15 September) during the four years in the five study sites (significant differences in predator/prey ratio have different letters $(\alpha=$ $0.05))$.

\begin{tabular}{|c|c|c|c|c|c|}
\hline \multirow[t]{2}{*}{ Site } & \multicolumn{5}{|c|}{ Thanasimus formicarius/Ips typographus ratios } \\
\hline & & 2001 & 2002 & 2003 & 2004 \\
\hline & Average & $1 / 2393^{\mathrm{A}}$ & $1 / 573^{\mathrm{B}}$ & $1 / 528^{\mathrm{B}}$ & $1 / 400^{\mathrm{C}}$ \\
\hline HA & $1 / 218^{\mathrm{A}}$ & $1 / 404$ & $1 / 191$ & $1 / 196$ & $1 / 80$ \\
\hline ST & $1 / 196^{\mathrm{B}}$ & $1 / 441$ & $1 / 115$ & $1 / 180$ & $1 / 46$ \\
\hline DO & $1 / 918^{\mathrm{C}}$ & - & $1 / 808$ & $1 / 878$ & $1 / 1067$ \\
\hline GU & $1 / 2195^{\mathrm{C}}$ & $1 / 6693$ & $1 / 1248$ & $1 / 495$ & $1 / 343$ \\
\hline $2 \mathrm{~L}$ & $1 / 975^{\mathrm{C}}$ & $1 / 2036$ & $1 / 503$ & $1 / 892$ & $1 / 468$ \\
\hline
\end{tabular}


Table V. Correlation between (a) Shannon diversity index (SHDI) and predator/prey ratio; (b) arcsine-transformed proportion of pines (PROP_PIN) and predator/prey ratio.

\begin{tabular}{|c|c|c|c|c|c|c|}
\hline $\begin{array}{l}\text { Landscape } \\
\text { characterization }\end{array}$ & Radius & Year & Number of categories & $N$ & $r$ (Pearson) & $P$ \\
\hline \multirow[t]{27}{*}{ SHDI } & STAND & 2001 & 15 & 4 & 0.327 & 0.673 \\
\hline & & & 8 & 4 & 0.348 & 0.652 \\
\hline & & & 6 & 4 & 0.348 & 0.652 \\
\hline & & & 5 & 4 & 0.423 & 0.577 \\
\hline & & & 4 & 4 & 0.367 & 0.633 \\
\hline & & & 3 & 4 & 0.549 & 0.451 \\
\hline & & 2002 & 3 & 5 & 0.314 & 0.607 \\
\hline & & 2003 & 3 & 5 & 0.375 & 0.533 \\
\hline & & 2004 & 3 & 5 & 0.359 & 0.553 \\
\hline & $500 \mathrm{~m}$ & 2001 & 15 & 4 & 0.788 & 0.212 \\
\hline & & & 8 & 4 & 0.845 & 0.155 \\
\hline & & & 6 & 4 & 0.843 & 0.157 \\
\hline & & & 5 & 4 & 0.863 & 0.137 \\
\hline & & & 4 & 4 & 0.713 & 0.287 \\
\hline & & & 3 & 4 & 0.919 & 0.081 \\
\hline & & 2002 & 3 & 5 & 0.969 & 0.006 \\
\hline & & 2003 & 3 & 5 & 0.962 & 0.009 \\
\hline & & 2004 & 3 & 5 & 0.972 & 0.006 \\
\hline & $1000 \mathrm{~m}$ & 2001 & 15 & 4 & 0.691 & 0.309 \\
\hline & & & 8 & 4 & 0.767 & 0.233 \\
\hline & & & 6 & 4 & 0.766 & 0.234 \\
\hline & & & 5 & 4 & 0.866 & 0.134 \\
\hline & & & 4 & 4 & 0.477 & 0.523 \\
\hline & & & 3 & 4 & 0.712 & 0.288 \\
\hline & & 2002 & 3 & 5 & 0.868 & 0.057 \\
\hline & & 2003 & 3 & 5 & 0.836 & 0.078 \\
\hline & & 2004 & 3 & 5 & 0.936 & 0.019 \\
\hline \multirow[t]{12}{*}{ PROP_PIN } & STAND & 2001 & 1 & 4 & 0.859 & 0.141 \\
\hline & & 2002 & 1 & 5 & 0.974 & 0.005 \\
\hline & & 2003 & 1 & 5 & 0.885 & 0.046 \\
\hline & & 2004 & 1 & 5 & 0.990 & 0.001 \\
\hline & $500 \mathrm{~m}$ & 2001 & 1 & 4 & 0.973 & 0.027 \\
\hline & & 2002 & 1 & 5 & 0.985 & 0.002 \\
\hline & & 2003 & 1 & 5 & 0.966 & 0.007 \\
\hline & & 2004 & 1 & 5 & 0.932 & 0.021 \\
\hline & $1000 \mathrm{~m}$ & 2001 & 1 & 4 & 0.964 & 0.036 \\
\hline & & 2002 & 1 & 5 & 0.975 & 0.005 \\
\hline & & 2003 & 1 & 5 & 0.974 & 0.005 \\
\hline & & 2004 & 1 & 5 & 0.936 & 0.019 \\
\hline
\end{tabular}

\subsection{Diversity indices}

The bivariate correlations between the predator/prey ratios in 2001 and the Shannon diversity index (SHDI) were the best within a $500 \mathrm{~m}$ radius and calculated with only 3 tree categories (pines, spruces and others) $(N=4 ; r=0.919 ; P=0.081)$
(Tab. V). Each year taken separately gave best correlation indices with SHDI as well as with PROP_PIN, within a $500 \mathrm{~m}$ radius. The bivariate correlations are significant for 2002, 2003 and $2004(P<0.01)$ with SHDI and significant with PROP_PIN $(P<0.05)$, despite the weak number of points on the graph ( 5 points). Taken separately, the two insect species were 
Table VI. Correlation between (a) Shannon diversity index (SHDI) and catches of T. formicarius and of I. typographus; (b) arcsine-transformed proportion of pines (PROP_PIN) and catches of T. formicarius and of I. typographus; in a 500 m radius.

\begin{tabular}{|c|c|c|c|c|c|c|}
\hline $\begin{array}{l}\text { Landscape } \\
\text { characterization }\end{array}$ & Species & Year & Number of categories & $N$ & $r$ (Pearson) & $P$ \\
\hline \multirow[t]{8}{*}{ SHDI } & T. formicarius & 2001 & 3 & 4 & 0.972 & 0.028 \\
\hline & & 2002 & 3 & 5 & 0.944 & 0.016 \\
\hline & & 2003 & 3 & 5 & 0.536 & 0.352 \\
\hline & & 2004 & 3 & 5 & 0.941 & 0.017 \\
\hline & I. typographus & 2001 & 3 & 4 & -0.704 & 0.296 \\
\hline & & 2002 & 3 & 5 & -0.604 & 0.280 \\
\hline & & 2003 & 3 & 5 & -0.857 & 0.064 \\
\hline & & 2004 & 3 & 5 & -0.810 & 0.096 \\
\hline \multirow[t]{8}{*}{ PROP_PIN } & T. formicarius & 2001 & 1 & 4 & 0.940 & 0.060 \\
\hline & & 2002 & 1 & 5 & 0.974 & 0.005 \\
\hline & & 2003 & 1 & 5 & 0.462 & 0.434 \\
\hline & & 2004 & 1 & 5 & 0.887 & 0.045 \\
\hline & I. typographus & 2001 & 1 & 4 & -0.798 & 0.202 \\
\hline & & 2002 & 1 & 5 & -0.783 & 0.118 \\
\hline & & 2003 & 1 & 5 & -0.911 & 0.032 \\
\hline & & 2004 & 1 & 5 & -0.866 & 0.057 \\
\hline
\end{tabular}

Table VII. Results of the linear regressions between (a) predator/prey ratio and Shannon diversity indices (SHDI), (b) predator/prey ratio and arcsine-transformed proportion of pines (PROP_PIN).

\begin{tabular}{|c|c|c|c|c|c|}
\hline Landscape characterization & Year & $N$ & $R^{2}$ & $P$ & Equation \\
\hline \multirow[t]{4}{*}{ PROP_PIN } & 2001 & 4 & 0.945 & 0.028 & $y=0.0013 x+0.0003$ \\
\hline & 2002 & 5 & 0.971 & 0.002 & $y=0.0045 x+0.0011$ \\
\hline & 2003 & 5 & 0.934 & 0.007 & $y=0.0016 x+0.0011$ \\
\hline & 2004 & 5 & 0.868 & 0.021 & $y=0.0079 x+0.0017$ \\
\hline \multirow[t]{4}{*}{ SHDI } & 2001 & 4 & 0.842 & 0.082 & $y=0.0108 x-0.0069$ \\
\hline & 2002 & 5 & 0.940 & 0.006 & $y=0.0343 x-0.0215$ \\
\hline & 2003 & 5 & 0.928 & 0.009 & $y=0.0125 x-0.0072$ \\
\hline & 2004 & 5 & 0.945 & 0.006 & $y=0.0638 x-0.0408$ \\
\hline
\end{tabular}

correlated with the two landscape characterization indices (SHDI and PROP_PIN) (Tab. VI): the catches of $T$. formicarius were positively correlated with SHDI $(P<0.05)$ with the exception of $2003(P=0.352)$, and with PROP_PIN $(P<0.05)$ with the exception of 2001 and $2003(P=0.060$ and 0.434$)$, while the catches of I. typographus were negatively correlated only with PROP_PIN $(P=0.032)$ in 2003.

Linear regressions calculated between the predator/prey ratios and both SHDI and PROP_PIN were different each year (Tab. VII).

\section{DISCUSSION}

\subsection{Trapping data}

One year after the heavy storms of December 1999, we expected to trap high numbers of Ips typographus, because north-eastern France was (with south-western France) one of the most heavily struck regions (Inventaire Forestier National: http://www.ifn.fr/pages/fr/tempetes/index.html). From June to September 2001, each group of ten traps set-up in each site caught more than 50000 Ips typographus (average per trap: $5457 \pm 2122$ ). After this successful trapping period, we expected increasingly lower catches during the following years because of restored tree resistance and naturally-occuring biocontrol by Thanasimus formicarius. Accordingly, the Ips typographus catches decreased every years but $T$. formicarius catches were higher in 2002, decreased in 2003 and increased again in 2004 (Fig. 1). The sudden decrease in T. formicarius catches in 2003 might perhaps be explained by the heat wave that struck France in July that year (Météo France : http://www.meteofrance.com/ FR/actus/dossier/archives/bilan2003/dos.htm), and which might have provided sub-optimal conditions for flight during that period. 


\subsection{Predator/prey ratios and diversity indices}

The T. formicarius/I. typographus ratios were significantly correlated with the Shannon diversity indices (SHDI) calculated within a $500 \mathrm{~m}$ radius and with only 3 tree categories (Tab. V), namely pines (favourable for the predator's reproduction), spruces (host-tree of the prey) and all other tree species (Tab. VI). However, the bivariate correlations between the predator/prey ratios and the proportions of pines within a $500 \mathrm{~m}$ radius around the traps were similar to those with SHDIs. As spruce was always present in all the stands sampled (a condition for including these stands in the experiments), spruce is a constant which does not enter into the correlations, which explains why it was principally the presence of pines that influenced the predator/prey ratios. This observation is supported by the higher T. formicarius catches and predator/prey ratios in the sites comprising pines (Hanau and Steinbach) as compared to those without pines (Guebwiller, Deux Lacs and Donon) (Tab. IV). These results corroborate those obtained in grid trapping experiments in Belgium (Warzée et al., submitted) which showed that $T$. formicarius catches are correlated with the proportions of pines around the traps, suggesting that pines would provide a complementary habitat [6] to the predators and act as "source" in a "source-sink" metapopulation dynamics [22, 23].

The possibility exists that the lower numbers of Ips typographus caught in the stands with high proportions of pine are due to lower host resources (spruce) concentration. In this case, the scarcity of bark beetles would have been driven by host availability and not by predation. However, unattacked spruces still remain in both stands and, in one site at least (Steinbach), large pure spruce stands of susceptible age ( $>50$ years) are immediately available within $100 \mathrm{~m}$ and could have served as supplementary resources. It is remarkable that these latter stands remained almost untouched throughout the whole study period, suggesting that the bark-beetle population in the infestation spot never grew large enough to threaten them.

The possible use of the T. formicarius/I. typographus ratios to predict Ips typographus population status, as done in the USA with the $T$. dubius/D. frontalis ratios [4] seems thus to depend, in France, on another variable, the proportion of pines within a $500 \mathrm{~m}$ radius.

We must remark that, because this study incorporates $T$. formicarius catches, it takes more into account the population dynamics of Ips typographus than did earlier approaches comparing only bark-beetle catches and tree mortality due to beetle attacks ([7]; Weslien et al. 1989, Lindelöw and Schroeder 2000 in [20]) or using sales of infested timber to assess the Ips typographus populations [8]. These earlier studies give instantaneous measures of risk-damages but no indications about the trends of the infestation.

Acknowledgements: We thank Drs G. Landman and L.M. Nageleisen (Direction de l'Espace Rural et de la Forêt) for their excellent project coordination, D. Adam, A. Brocard, F. Durmann, M. Mathieu, M. Muller, G. Peter, P. Schlosser, H. Schmuck and P. Stoquert for their help in the field, and Thibaut Defrance and Julien Oversteyns for their help in sorting and counting the catches. Prof. Jan Bogaert (Laboratory of Landscape Ecology, ULB) provided useful advices for the calculation of the Shannon index and critically commented the manuscript. Mr. Claude Mathis (Inventaire Forestier National, Nancy, France) kindly provided the aerial photographs of the five sites. This study was financed by the Direction Générale de la Forêt et des Affaires Rurales. The authors acknowledge the Fonds pour la Formation à la Recherche dans l'Industrie et l'Agriculture (FRIA) and the Fonds National de la Recherche Scientifique (FNRS) for financial support. A grant from the Fonds pour la Recherche Fondamentale Collective (FRFC No 2.4578.99) covered some of the project's costs.

\section{REFERENCES}

[1] Anonyme, Predicting Southern Pine Beetle Trends (Cooperative Efforts Provide a Better Crystal Ball), Forest Landowner (1997) $36-37$.

[2] Bakke A., Kvamme T., Kairomone response in Thanasimus predators to pheromone components of Ips typographus, J. Chem. Ecol. 7 (1981) 305-312.

[3] Balachowsky A., Faune de France. 50: Coléoptères Scolytides, Editions Paul Lechevalier, Paris, 1949, 320 p.

[4] Billings R.F., Forecasting southern pine beetle infestation trends with pheromone traps, in: Payne T.L., Saarenmaa H. (Eds.), IUFRO Symposium: Integrated Control of Scolytid Bark Beetles, Vancouver, B.C. Canada, Virginia Polytechnic Institute and State University, Blacksburg, VA, 1988, pp. 295-306.

[5] Dippel C., Heidger C., Nicolai V., Simon M., The influence of four different predators on bark beetles in European forest ecosystems (Coleoptera: Scolytidae), Ent. Gen. 21 (1997) 161-175.

[6] Dunning J.B., Banielson B.J., Pulliam H.R., Ecological processes that affect population in complex landscapes, Oikos 65 (1992) 169-175.

[7] Faccoli M., Stergulc F., Ips typographus (L.) pheromone trapping in south Alps: spring catches determine damage thresholds, JEN 128 (2004) 307-311

[8] Franklin A., De Cannière C., Grégoire J.C., Can sales of infested timber be used to quantify attacks by Ips typographus (Coleoptera, Scolytidae)? A pilot study from Belgium, Ann. For. Sci. 61 (2004) 477-480.

[9] Gauss R., Der Ameisenbuntkäfer Thanasimus (Clerus) formicarius Latr. als Borkenkäferfeind, in: Wellenstein G. (Ed.), Die grosse Borkenkäferkalamität in Südwest-Deutschland 1944-1951, Forstschutzstelle Südwest/Ringingen, 1954, pp. 417-429.

[10] Gilben M., Nageleisen L.M., Franklin A., Grégoire J.C., Post-storm surveys reveal large-scale spatial patterns and influences of site factors, forest structure and diversity in endemic bark-beetle populations, Landsc. Ecol. (2005) 35-49.

[11] Grégoire J.C., Piel F., De Proft M., Gilbert M., Spatial distribution of ambrosia-beetle catches: a possibly useful knowledge to improve mass-trapping, IPM Reviews 6 (2001) 237-242.

[12] Grégoire J.C., Evans H.F., Damage and control of BAWBILT organisms - an overview, in: Lieutier F., Day K., Battisti A., Grégoire J.C., Evans H. (Eds.), Bark and Wood Boring Insects in Living Trees in Europe, a Synthesis, Kluwer, Dordrecht, 2004, pp. 19-37.

[13] Hérard F., Mercadier G., Natural enemies of Tomicus piniperda and Ips acuminatus (Col., Scolytidae) on Pinus sylvestris near Orléans, France: temporal occurrence and relative abundance, and notes on eight predatory species, Entomophaga 41 (1996) 183-210.

[14] Kohnle U., Vité J.P., Bark beetle predators: strategies in the olfactory perception of prey species by clerid and trogositid beetles, Z. Angew. Entomol. 98 (1984) 504-508.

[15] McGarigal K., Marks B.J., FRAGSTATS: spatial pattern analysis program for quantifying landscape structure, US Department of Agriculture, Forest Service, Pacific Northwest Research Station, 1995. 
[16] Mills N.J., The natural enemies of scolytids infesting conifer bark in Europe in relation to the biological control of Dendroctonus spp. in Canada, Biocontrol News and Information 4 (1983) 305-328.

[17] Mills N.J., Some observations on the role of predation in the natural regulation of Ips typographus populations, Z. Angew. Entomol. 99 (1985) 209-215.

[18] Mills N.J., A preliminary analysis of the dynamics of within tree populations of Ips typographus (L.) (Col. : Scolytidae), J. Appl. Entomol. 102 (1986) 402-416.

[19] Nagendra H., Opposite trends in response for the Shannon and Simpson indices of landscape diversity, Appl. Geogr. 22 (2002) 175-186.

[20] Økland B., Berryman A., Resource dynamic plays a key role in regional fluctuations of the spruce bark beetles Ips typographus, Agric. For. Entomol. 6 (2004) 141-146.

[21] Pfeffer A., Zentral- und Westpaläarktische Borken- und Kernkäfer (Coleoptera, Scolytidae, Platypodidae), Entomologica Basiliensia 17 (1994) 5-310.

[22] Pulliam H.R., Sources, sinks, and population regulation, Am. Nat. 132 (1988) 652-661.
[23] Pulliam H.R., Danielson B.J., Sources, sinks, and habitat selection: a landscape perspective on population dynamics, Am. Nat. 137 (1991) S50-S66.

[24] Reeve J.D., Predation and bark-beetle dynamics, Oecologia 112 (1997) 48-54.

[25] Shannon C.E., A mathematical theory of communication, ATT Tech. J. (1948) 27: 379-423; 623-656.

[26] Shannon C.E., Weaver W., The mathematical theory of communication, University of Illinois Press, 1949.

[27] Tømmerås B.A., The clerid beetle Thanasimus formicarius is attracted to the pheromone of the ambrosia beetle Trypodendron lineatum, Experientia 44 (1988) 536-537.

[28] Turchin P., Taylor A.D., Reeve J.D., Dynamical role of predators in population cycles of a forest insect: an experimental test, Science 285 (1999) 1068-1071.

[29] Weslien J., The arthropod complex associated with Ips typographus (L.) (Col., Scolytidae): species composition, phenology, and impact on bark beetle productivity, Entomol. Fenn. 3 (1992) 205-213.

[30] Weslien J., Regnander J., The influence of natural enemies on brood production in Ips typographus (Col.: Scolytidae) with special reference to egg-laying and predation by Thanasimus formicarius (Col.: Cleridae), Entomophaga 37 (1992) 333-342. 